\title{
Comparison of Social Skills of Primary School Children With and Without Parents With Mental Disorders
}

\author{
Farshid Shamsaei ${ }^{1}, Z_{\text {Zahra Shookohi }}^{2}$, Maryam Farhadiayn ${ }^{3}$, Efat Sadeghian $^{4 *}$
}

1. Associate Professor, Department of Nursing, Mother and Child Care Research Center, Hamadan University of Medical sciences, Hamadan, Iran

2. MSc. Student, Faculty of Nursing and Midwifery, Hamadan University of Medical Sciences, Hamadan, Iran

3. Assistant Professor, Department of Biostatistics, Hamadan University of Medical Sciences, Hamadan, Iran

4. Assistant Professor, Department of Nursing, Chronic Diseases (Home Care) Research Centre, Hamadan University of Medical Sciences, Hamadan, Iran

\section{Article Info \\ Received: $\quad$ 2018/06/10 \\ Accepted: $\quad 2018 / 10 / 10$ \\ Published Online: 2019/05/22}

DOI: $10.30699 /$ sjhnmf.27.2.97

Original Article

Use your device to scan and read the article online

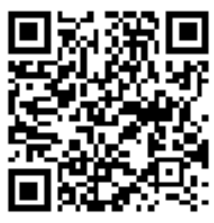

\section{Abstract}

Introduction: Social skills are considered to be one of the important factors in the success or failure of every individual in a society. The present study was designed to determine the social skills of primary school children with and without parents of mental disorders.

Methods: In this research 60 kids between 6-12 years were selected using available sampling method, who had parents with mental disorder in addition to 60 kids at the same age who didn't have parents with mental disorder. Research setting was Farshchian hospital in Hamadan city in 2017. Data was collected with demographic questionnaire and Gresham and Eliot with category scale of social skills that was completed by parents. Data was analyzed using SPSS 21 and descriptive statistics and inferential statistics including $\mathrm{T}$ test, covariance analysis and Chi-square test.

Result: The score of social skill in kids who had parents with mental disorder was $56.43 \pm 10.8$ and in kids who didn't have parents with mental disorder was 58.46 \pm 8.70 . Comparing social skills in two groups showed that they are not significant difference in mean Score in social skills and its dimensions (cooperation, decisiveness, selfcontrol and responsibility). Although there aren't significant difference between two groups, mean score in witness group was more than another group $(P=0.259)$.

Conclusion: The social skills of children in both groups were at the medium range and were not of a desirable level. This calls for a review of family-based education and educational approaches, as well as training programs to promote social skills.

Keywords: Parents, Social Skills, Children in Primary School, Mental Disorders
Corresponding Information

Efat Sadeghian, Assistant Professor, Department of Nursing, Chronic Diseases (Home Care) Research Centre, Hamadan University of Medical Sciences, Hamadan, Iran. Email: sadeghianefat@gmail.com

Copyright (C) 2019, This is an original open-access article distributed under the terms of the Creative Commons Attribution-noncommercial 4.0 International License which permits copy and redistribute of the material just in noncommercial usages with proper citation. 


\section{مجلة مراقبت يرستارى و مامايى ابن سينا - شايا الكترونيك: بVY-AVFA

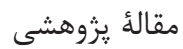

مقايسهُ مهارتهاى اجتماعى كودكان سن دبستان با والدين مبتلا به اختلال روانى و بدون والدين مبتلا به

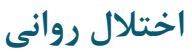

فر شيد شمسايى'، زهرا شكوهى'، مريم فرهاديان"، عفت صادقيان"

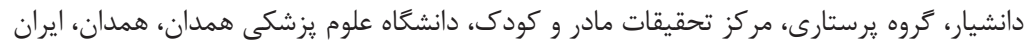

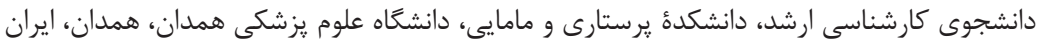

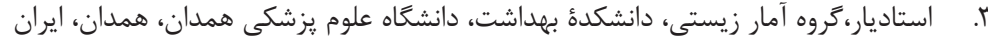

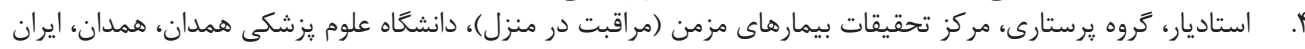

\begin{tabular}{|c|c|}
\hline קكيده & اطلاعات مقاله \\
\hline 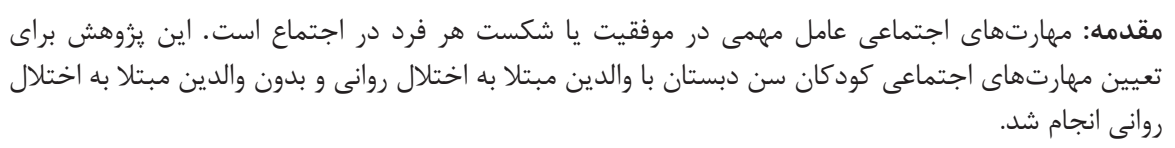 & 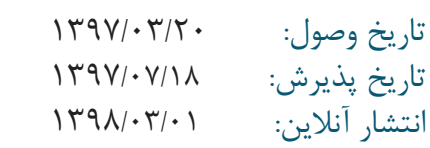 \\
\hline  & 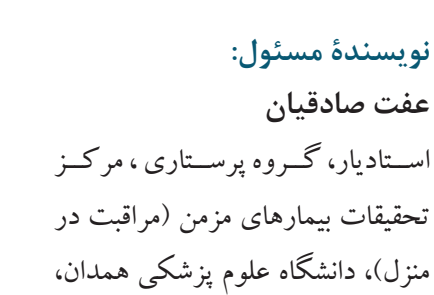 \\
\hline 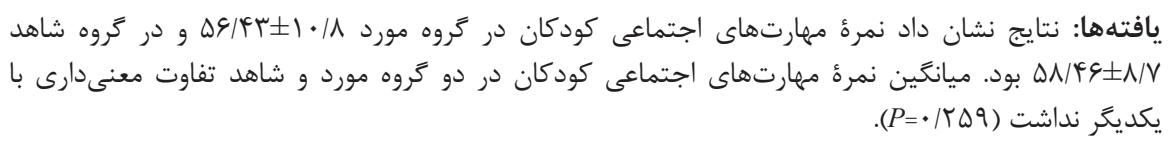 & همدان، ايران \\
\hline 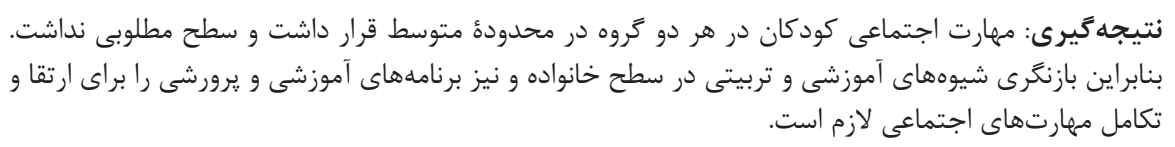 & $\begin{array}{c}\text { يست الكترونيك:.com } \\
\text { sadeghianefat@gmail.com }\end{array}$ \\
\hline كليدوازهها: والدين، مهارتهاى اجتماعى، كودكان & \\
\hline
\end{tabular}

مقدمه

به عرصههاى مختلف اجتماع داشته باشند تا تعاملات يايدار

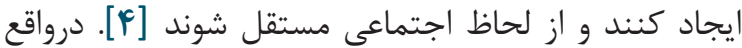
كسب مهارتهاى اجتماعى در كودكان بخشى از فرايند

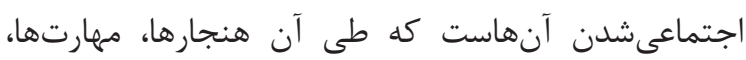


اجتماعى كودكان تأثير شكرفى در كاركردهاى انطباقى،

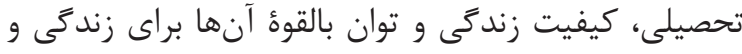
آموزش در محيط با حداقل محدوديت دارد. متأسفانه تعـداد

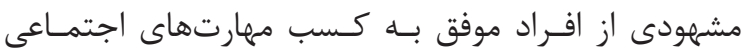

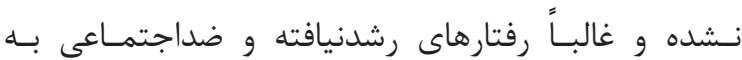

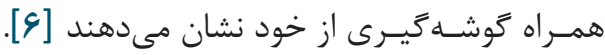
كمبود مهارتهاى اجتماعى كودكان را با مشكلات متعدد مواجه مى كند و باعث ناساز واختلالات رفتارى مىشود. همجنين بر رشد شخصيت
انسان موجودى اجتماعى است و براى اينكه بتواند به حيات خود ادامه دهد بايد با همنوعان خود سازكارى و همنوايى داشته باشد. داشتن ارتباط مناسب در سائ

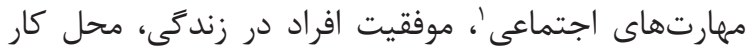

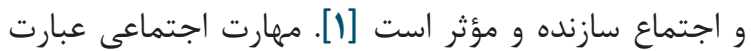
است از: مجموعهاى از رفتارهاى هدفمند، به هم مرتبط و

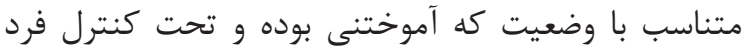

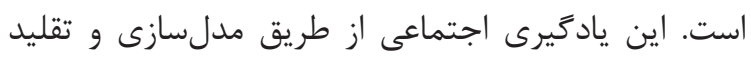

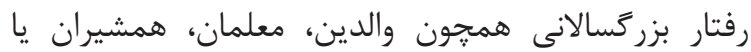
همسالان صورت مىيذيرد [T]. مهارت اجتماعى رفتارهايى لريى

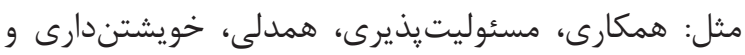

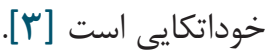
كودكان بايد خزانهاى از مهارتهاى اجتماعى براى ورود

1. Social Skills 
به سلامتى آنها بستگى دارد. بنابراين كودكان بايد خزانهاى از مهارتهاى اجتماعى براى ورود به عرصههاى مختلف بارئل اجتماع داشته باشند تا تعاملات يايدار ايجاد كنند و از لحاظ وراظ اجتماعى مستقل شوند. بررسى كودكانى كه والدين مبتلا به اختلالات روانى دارند در مشخص كردن ميزان توانايى مهارت اجتماعى اين كودكان كمك بسيارى مى كند؛ جون اختلال

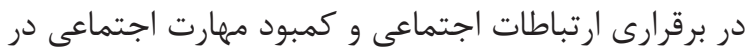

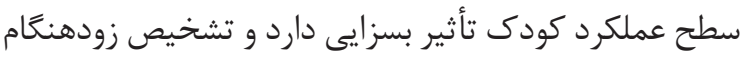
اختلال در مهارتهاى اجتماعى، پيشگيرى از پيامدهاى

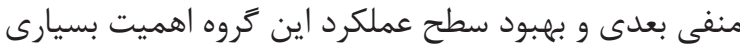

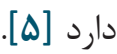

يرستاران به عنوان يكى از مهمهرين اعضاى تيم سلامت نقشهاى مختلفى در ارتقاى سلامت كودكان و پيشگيرى

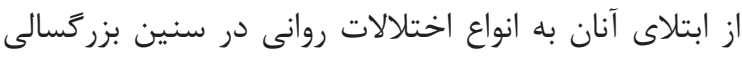

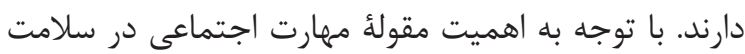
افراد يزوهشى با هدف مقايسٔ مهارتهاى اجتماعى كودكان، در سن دبستان، با والدين مبتلا به اختلالات روانى و كودكانى

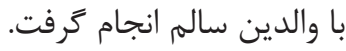

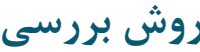

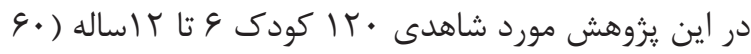
كودى با والد مبتلا به اختلال روانى و •9 كودى با والدين بدون اختلال روانى) به روش نمونه گيرى دردسترس انتخاب

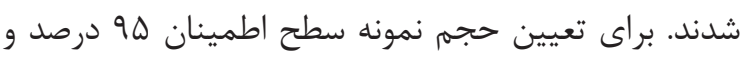

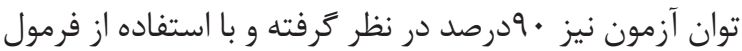

$$
n=\frac{\left(\sigma_{1}^{2}+\sigma_{2}^{2} \gamma_{1-\frac{\alpha}{2}}+z_{1-\beta}\right)^{2}}{\left(\mu_{1}-\mu_{2}\right)^{2}}
$$

محيط يزوهش مركز آموزشى درمانى فرشجيان همدان در

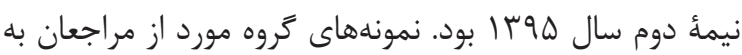
درمانكاهها و بخشهاى روانيزشكى و نمونههاى كروه شاهد از مراجعان به درمانكاههاى جسمى مركز آموزشى درمانى

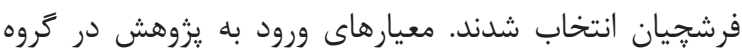

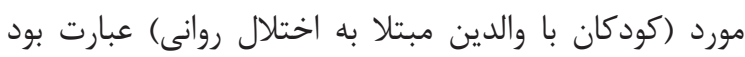

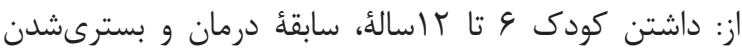
يك والد در بخش روانيزشكى با تشخيص (افسردىى اساسى،

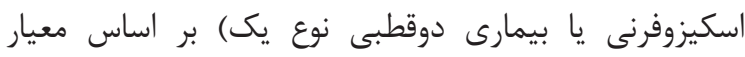

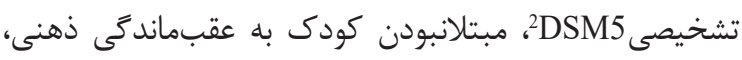

كودى و سازگارى وى با محيط تأثير منفى مى گذارد كه پيشايندهاى بالقوه را براى اختلالات روانشناختى نشان مىدهد [V]. اهميت مهارتهاى اجتماعى به عنوان

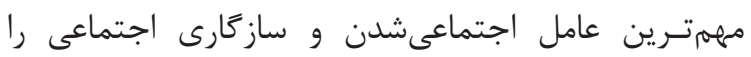

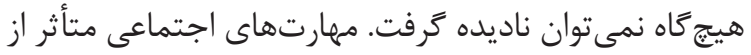
سطوح مختلف بومشناختى، شامل خانواده، مدرسه و جامعه

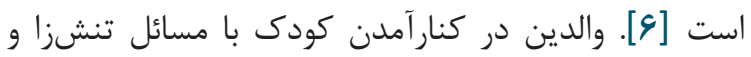
همرجنين كاهش مشكلات رفتارى وى نقش بسزايى دارند، زيرا ميزان مهارتهاى اجتماعى فرد، بهطورمستقيم، به تعداد و نوع اعمال اجتماعى مطلوبى مربوط مىشود كه ديكران

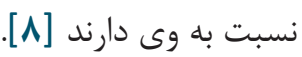
اختلالهاى روانى در يدر و مادر فرزندان را دجار مشكل مى كند، زيرا استعداد اختلال هاى روانى را به فرزندان منتقل و ايفاى نقش همسرى و والدى را در خانواده دشوار مى كند. ندان.

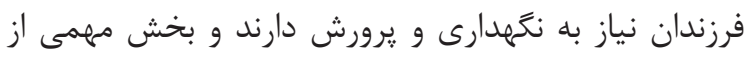

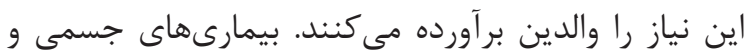

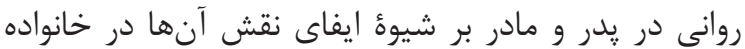

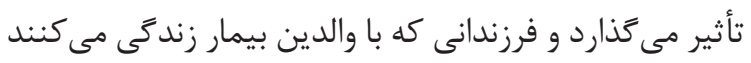

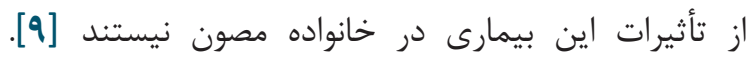

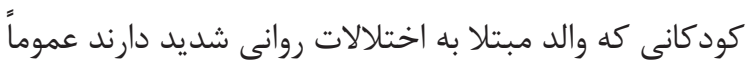
با مشكلات عصبى و ناميدىهاى زيادى در زندگى مواجه

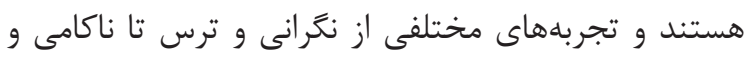
خشم، به شيوههاى مختلف، دارند [F]. دستيابى به جامعهُ سالم در گرو سلامت خانواده و تحقق

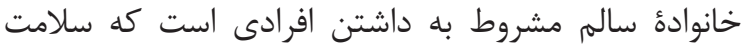

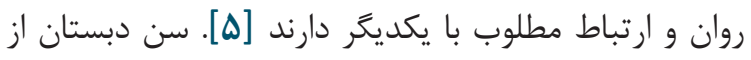
حساسترين دورههاى رشد است. در اين دوره كه شخصيت

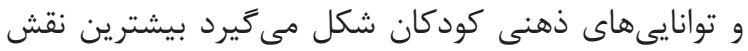
را الكوهاى رفتارى دارند. درواقع ويزَّى الكَ كه عمدتاً



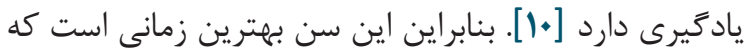

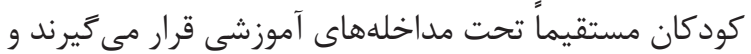
درحقيقت به افزايش توانمندى و رشد مهارتهاى اجتماعى مدى ماتى

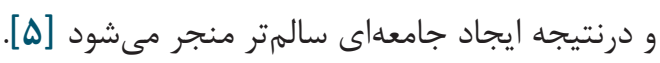
بررسىها نشان مىدهد عوامل متعددى، مانند: اشتغال و تحصيلات والدين، جنسيت كودكان، اعتياد والدين، بيمارى كودكان بر ميزان مهارت اجتماعى كودكان تأثيركذار است است

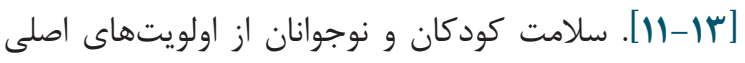
سيستم بجداشتى در همأ كشورهاست، زيرا آيندة هر كشور 
》بعضى اوقاتش نمره يك و به گزينه 》اغلب اوقاته نمرهٔ دو تعلق مى گيرد. بخش مهارتهاى اجتمـاعى شـامل رفتارهـايى

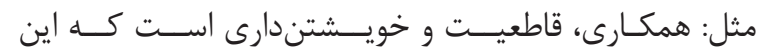
بخشها بــهـ صــورت خردهآزمون ارائه شدهاند و از جمع نمرات

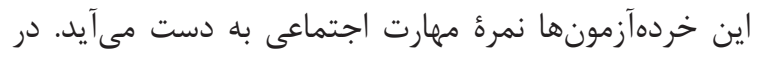

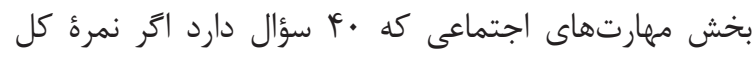
درمجموع بين صفر تا FV باشد مهارت اجتماعى در سطح يايين،


باشد بالاترين ميزان تعاملات اجتماعى كسب شده است. در هر

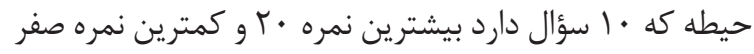
است. همجنين بخش مشكلات رفتارى r ا سؤال دارد كه صفر

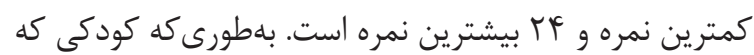

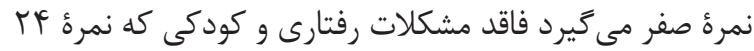
مى گيرد بيشترين مشكل رفتارى را دارد.

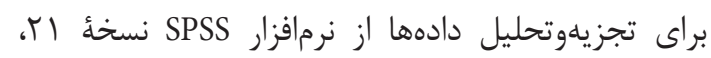
براى توصيف اطلاعات از آمار توصيفى و براى تحليل دادهها از آزمونهاى آمار استنباطى، شامل تى تست، آناليز كوواريانس

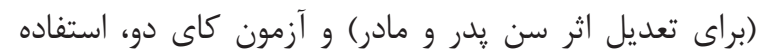

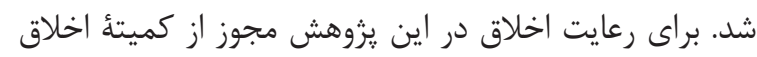

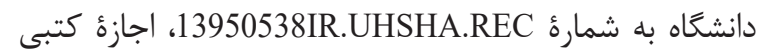
و معرفىنامه از معاونت يزوهشى دانشگاه علوم يزشكى همدان

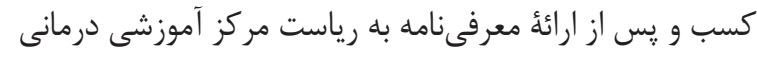

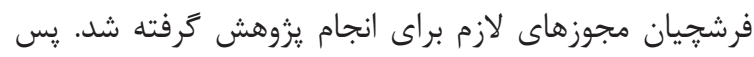

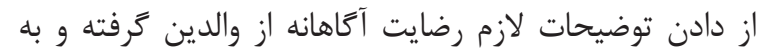
مشاركتكنندكًان اطمينان داده شد كه تمام اطلاعات آنهات آنها كاملاً محرمانه است.

بافتهها

تحليل دادههاى يزوهش نشان مى دهد كه Q

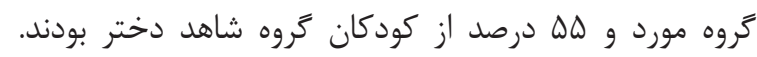
هلدرصد از والدين مبتلا به اختلال روانى در گروه مورد يدران

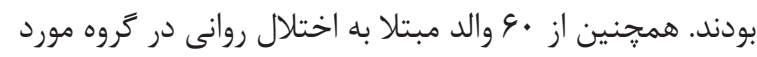

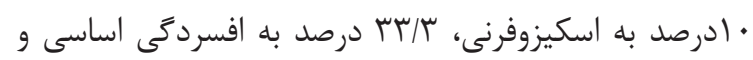
D\&/V درصد به بيمارى دوقطبى نوع يك مبتلا بودند (جدول ()).

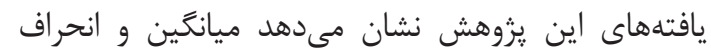

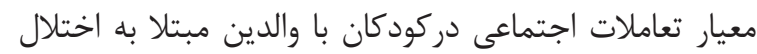

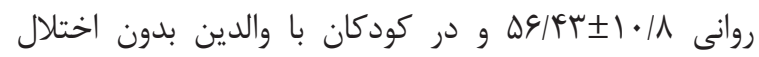

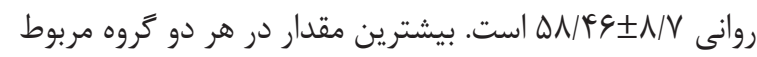

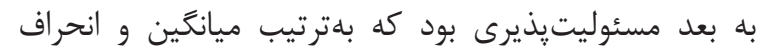
معيار,
مبتلانبودن كودى به بيمارى مزمن جسمى، نداشتن سابقه بيمارى روانى والد تكميلكننده يرسشنامه، حضور هردو والد بـ بردي در خانواده و نداشتن سابقه جدايى يا طلاق، رضايت براى ورود به يزوهش و داشتن حداقل سواد خواندن و نوشتن والدين. معيارهاى ورود به يزوهش در گروه شاهد علاوه بر معيارهاى ذكرشده نداشتن سابقهُ اختلال روانيزشكى و مصرف نكردن داروهاى روانى توسط والدين و معيار خروج در هردو گروه تكميل ناقص يرسشنامه بود. يثوهشگَ براى شروع نمونه گيرى با مراجعه به درمانگًاه

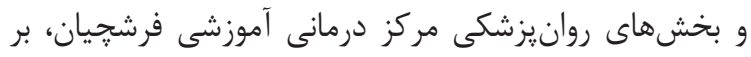
اساس معيارهاى ورود به يزوهش، والدين با تشخيص اختلال دوقطبى نوع يك، اسكيزوفرنى يا افسردكى اساسى را، كه بر بر بـ اساس معيار تشخيص DSM-DSM و نظر روانيزشك تحت درمان بودند، شناسايى كرده و اخر فرزند سن دبستان داشتند هماهنكَى لازم را براى حضور والد بدون اختلال روانى، كه توانايى ارزيابى دُني مناسب و جامعى از كودى داشته، انجام داد. نمونههاى گر روه شاهد والدين بدون اختلال روانى مراجعهكننده به تمام درمانگاههاى جسمى مركز آموزشى درمانى فرشجيان بودند كه

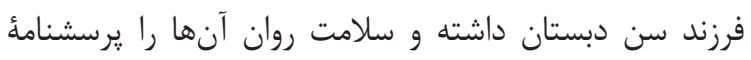
مشخصات دموگرافيك، نداشتن سابقة بيمارى روانيزشكى، مصرفنكردن داروهاى روانى تأييد كرد. يزوهشگر براى تكميل

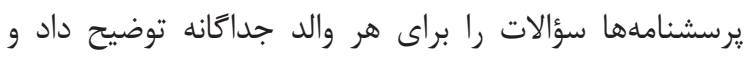
جواب سؤالات را خودش تكميل كرد. در اين يزوهش براى جمعآورى دادها از دو يرسشنامه

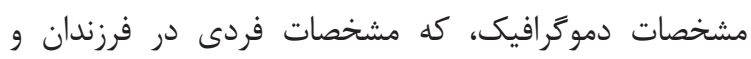
والدين را بررسى مى كند، و پرسشنامهُ نظام سنجش مهارت

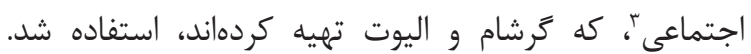
يرسشنامهٔ نظام سنجش مهارت اجتماعى مقياس درجهبندى هنجار مرجع است كه براى سنجش كاركرد اجتماعى كودكان ييشدبستانى تا يائه دوازدهم به كار مىرود. سه نسخه از ابزار

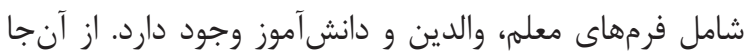
كه والدين درخصوص مهارتهاى اجتماعى فرزندان جامعترين اطلاعات را دارند در اين يزوهش از نسخهُ والدين استفاده و

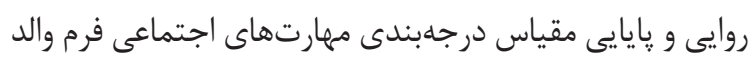

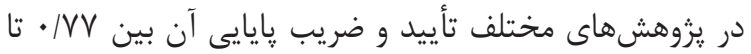

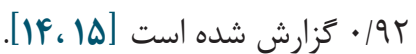
گَويههاى هر مقياس بر اساس فراوانى رفتار (هرگز، برخى اوقات و اغلب اوقات) درجهبندى مىشود. براى نمرهزذارى برى

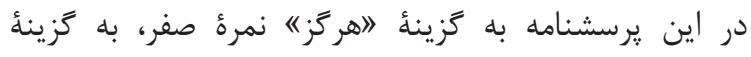

3. Standardization of Social Skills Rating System (SSRS)

مجلئ مراقبت يرستارى و مامايى ابنسينا 


$$
\text { مهارتهاى اجتماعى كودكان و همجنين ابعاد آن (همكارى، }
$$

جدول ا. توزيع فراوانى مطلق و نسبى اطلاعات دموَّرافيك گروه شاهد و مورد

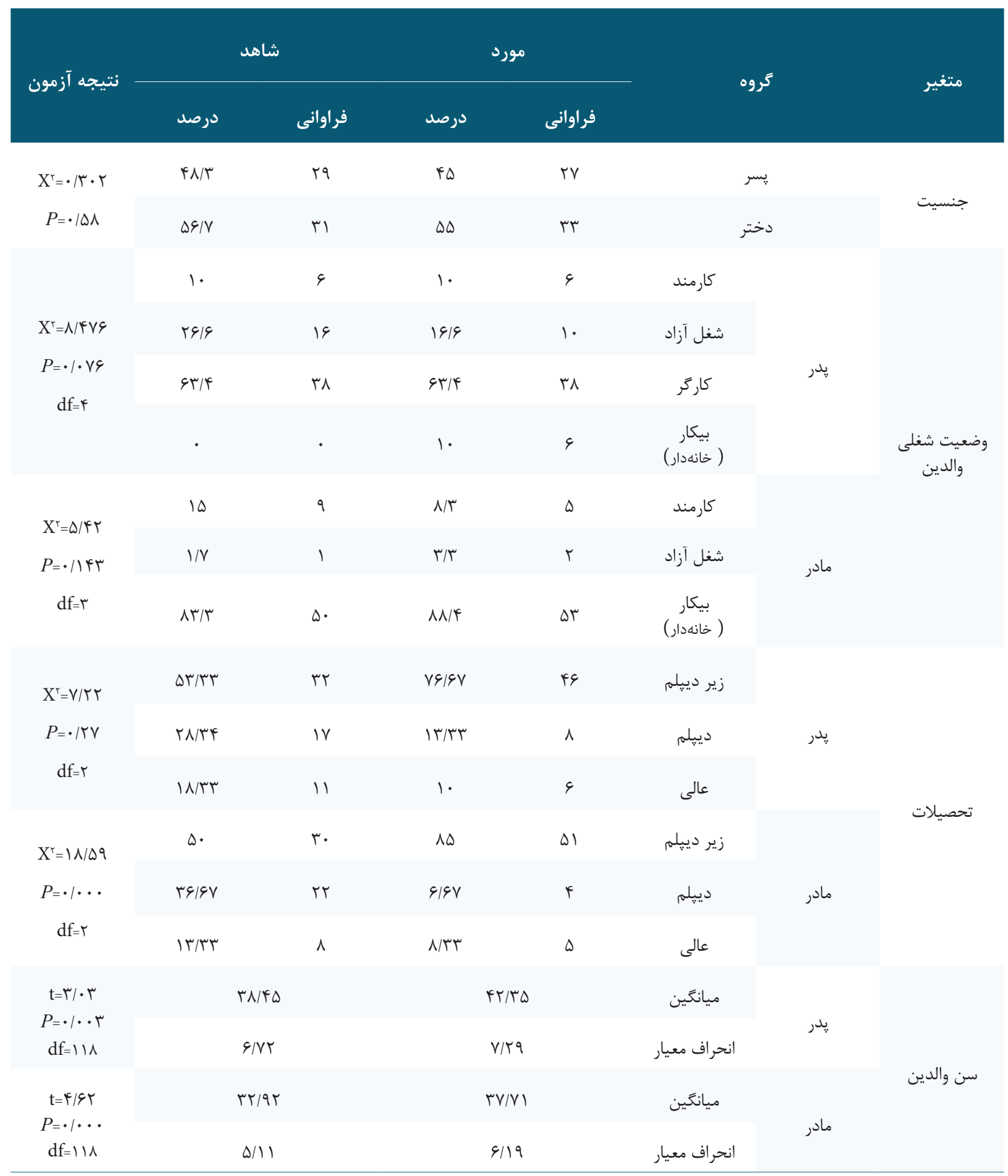


جدول r. مقايسُٔ ميانگين نمرات مهارتهاى اجتماعى و ابعاد آن در دو گروه مورد و شاهد

\begin{tabular}{|c|c|c|c|}
\hline \multirow{2}{*}{ نوع آزمون ANCOVA } & \multicolumn{2}{|c|}{ تروه } & \multirow{3}{*}{ متغير } \\
\hline & شاهد & مورد & \\
\hline$P$ & ميانغين士انحراف معيار & ميانگين士انحراف معيار & \\
\hline . IVED & $\mid r / \& \Delta \pm r / \wedge \Delta$ & $\mid r / r T \pm r / V q$ & بعد همكارى \\
\hline .1919 & $\mid Q / T r \pm \pm r / \cdot V$ & $\mid \Delta / 1 \Lambda \pm r / V r$ & بعد قاطعيت \\
\hline$\cdot|4|$ & $\mid r / \& V \pm T / \Delta \Delta$ & $\| / V r \pm F / F \Delta$ & بعد خويشتندارى \\
\hline.$/ 1 \vee 9$ & $\mid \varepsilon / \Lambda T \pm r / \Delta \Delta$ & $19 / \pi T \pm T / T V$ & بعد مسئوليت \\
\hline س & $\Delta \Lambda / \uparrow \& \pm \Lambda / V$. & $\Delta \&|\mathcal{F} \pm I \cdot| \Lambda \mid$ & كل \\
\hline
\end{tabular}

نتايج آزمون آمارى آناليز كوواريانس نشان مىدهد

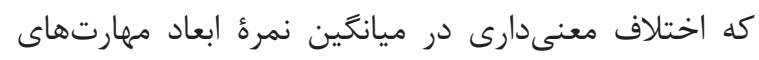
اجتماعى بين كودكان بر اساس والد بيمار وجود ندارد

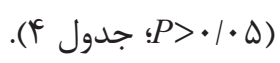

با تقسيمبندى نمرة كل مهارتهاى اجتماعى به سه سطح

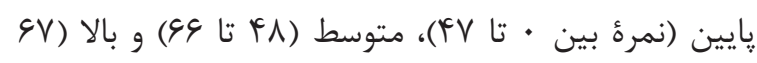

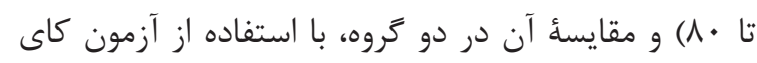
دو، نتايج اين آزمون نشان مىدهد كه دو گروه مورد و شاهد از نظر فراوانى سطوح مهارتهاى اجتماعى تفاوت آمارى

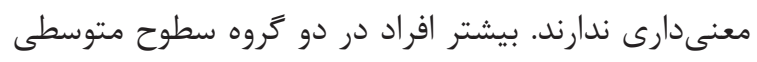
از مهارتهاى اجتماعى دارند (جدول ه).
نتايج نشان مىدهد در گروه مورد ميانگين و انحراف

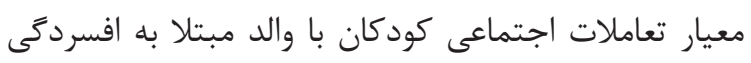


مقايسُٔ ميانخين و انحراف معيار در ابعاد مختلف مهارتهاى اجتماعى در بيمارىهاى مختلف نشان مى دهد كه بيشترين

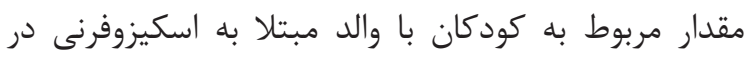

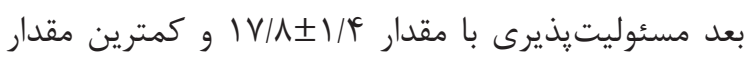

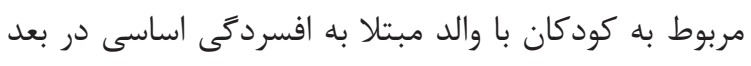

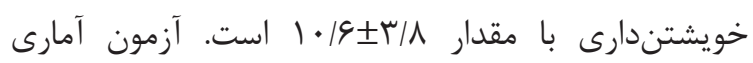
ANCOVA

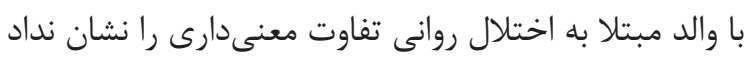

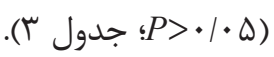

جدول ץ. مقايسُٔ مهارتهاى اجتماعى در كودكان كروه مورد بر حسب نوع بيمارى والد در ابعاد مختلف

\begin{tabular}{|c|c|c|c|c|c|}
\hline \multicolumn{2}{|c|}{ نوع تست ANCOVA } & \multicolumn{2}{|c|}{ نوع تست one way } & \multirow{2}{*}{ نوع بيمارى } & \multirow{2}{*}{ متغير } \\
\hline $\mathbf{F}$ & $\boldsymbol{P}$ & انحراف معيار & ميانَين & & \\
\hline \multirow{4}{*}{ •/VIS } & \multirow{4}{*}{. $/ 4 q 4$} & $1 / V \Delta$ & $\mid r / r$ & اسكيزوفرنى & \multirow{4}{*}{ همكارى } \\
\hline & & r/D६ & $\mid r / \Delta$ & دوقطبى نوع يك & \\
\hline & & $\varphi / 9$ & $I T / \Lambda$ & افسردى اساسى & \\
\hline & & r/vq & Ir/T & كل & \\
\hline \multirow{4}{*}{$\cdot|F| A \mid$} & \multirow{4}{*}{.1949} & $r / Y \wedge$ & ID/Ar & اسكيزوفرنى & \multirow{4}{*}{ قاطعيت } \\
\hline & & T/9D & $\mid F / \Lambda$ & دوقطبى نوع يك & \\
\hline & & $r / Y \varphi G$ & $10 / 0$ & افسردىى اساسى & \\
\hline & & $T / N r$ & $\mid \Delta / 1 \Lambda$ & كل & \\
\hline
\end{tabular}




\begin{tabular}{|c|c|c|c|c|c|}
\hline \multicolumn{2}{|c|}{ نوع تست ANCOVA } & \multicolumn{2}{|c|}{ نوع تست one way } & \multirow{2}{*}{ نوع بيمارى } & \multirow{2}{*}{ متغير } \\
\hline $\mathbf{F}$ & $P$ & انحراف معيار & ميانگين & & \\
\hline \multirow{4}{*}{$1 / \cdot \Delta \varphi$} & \multirow{4}{*}{$\cdot / r \Delta \Delta$} & $4 / \cdot \Lambda$ & $11 / 0$ & اسكيزوفرنى & \multirow{4}{*}{ خويشتندارى } \\
\hline & & $f / \Lambda$ & $|r / F|$ & دوقطبى نوع يك & \\
\hline & & r/A & $1 \cdot 190$ & افسردىى اساسى & \\
\hline & & $F / F F$ & $11 / V$ & كل & \\
\hline \multirow{4}{*}{.$/ 919$} & \multirow{4}{*}{$\cdot / r \Lambda}$. & $1 / F V$ & $I V / \Lambda$ & اسكيزوفرنى & \multirow{4}{*}{ مسئوليت ذِيرى } \\
\hline & & $r / 19$ & $I \Delta / V$ & دوقطبى نوع يك & \\
\hline & & r/99 & $18 / \mathrm{V}$ & افسردكى & \\
\hline & & T/TV & $|\varepsilon / \pi|$ & كل & \\
\hline \multirow{4}{*}{. T\& } & \multirow{4}{*}{$\cdot / V V$} & $\Delta / Y \Lambda$ & $\Delta V / \Delta$ & اسكيزوفرنى & \multirow{4}{*}{ مهارت اجتماعى } \\
\hline & & $11 / 9 \wedge$ & $\Delta \xi \mid \varepsilon \psi$ & دوقطبى نوع يك & \\
\hline & & $1 \cdot / 9 V$ & $\Delta \Delta / 1 \varphi$ & افسردگى اساسى & \\
\hline & & $1 \cdot 11$. & $\Delta s / T \Delta$ & كل & \\
\hline
\end{tabular}

جدول f. مقايسةٔ مهارتهاى اجتماعى و ابعاد آن در كروه مورد بر حسب والد بيمار

\begin{tabular}{|c|c|c|c|c|c|}
\hline t-test نوع آزمون & انحراف معيار & ميانكين & فراوانى & والد & متغير \\
\hline .1049 & r/lr & $|r / A|$ & r & يدر & \multirow{2}{*}{ همكارى } \\
\hline - MAST & $\varphi / \uparrow \wedge$ & $1 \% / 99$ & rV & مادر & \\
\hline . $/ q \Delta r$ & $r / 9$. & $|\Delta / r|$ & rr & يدر & \multirow{2}{*}{ قاطعيت } \\
\hline$\cdot \mid \Delta G Y$ & r/9 & $|Q / /|^{f}$ & rV & مادر & \\
\hline | & $r / .9$ & 19199 & זr & يدر & \multirow{2}{*}{ مسئوليتيذيرى } \\
\hline - $\mid 9 V F$ & $r / \omega$. & $1 \Delta / \wedge \Delta$ & TV & مادر & \\
\hline$\cdot / 1 \cdot r$ & $r / 9$. & $11 / 9$. & r & يدر & \multirow{2}{*}{ خويشتندارى } \\
\hline - MTK & r/Tr & $11 / 1$ & rV & مادر & \\
\hline
\end{tabular}

جدول ه. مقايسُٔ سطوح مهارتهاى اجتماعى در دو كروه مورد و شاهد

\begin{tabular}{|c|c|c|c|c|c|}
\hline \multirow{2}{*}{ آزمون كاى دو } & \multicolumn{2}{|c|}{ شاهد } & \multicolumn{2}{|c|}{ مورد } & \multirow{2}{*}{$\begin{array}{c}\text { سطح مهارتهاى اجتماعى } \\
\text { اجماى }\end{array}$} \\
\hline & درصد & تعداد & درصد & تعداد & \\
\hline  & 1. & 4 & $r$. & Ir & كم \\
\hline \multirow{2}{*}{$d f=r$} & VA/r & FV & $g r / r$ & rᄉ & متوسط \\
\hline & $11 / V$ & v & $19 / V$ & 1 . & زياد \\
\hline $\mathrm{P}=\cdot / 1 \mathrm{~V} \Delta$ & $1 \cdots$ & द. & $1 \ldots$ & q. & كل \\
\hline
\end{tabular}


رفتارى در كودكان ץ تا عساله را نشان مىدهد كه نتايج اين

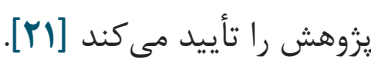

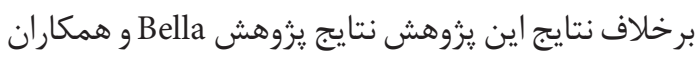
(Y.11) كودكان با والدين مبتلا به اختلال دوقطبى" نشان مى دهد

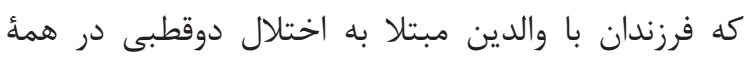

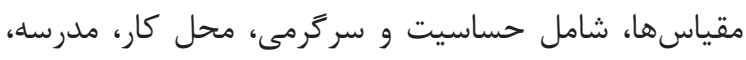

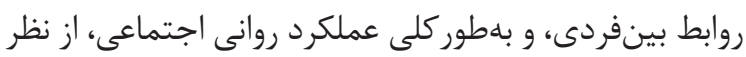

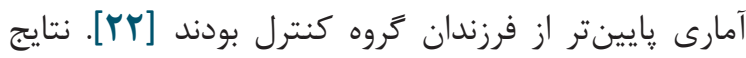

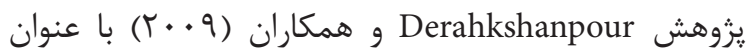
الاختلالات روانيزشكى و سطح عملكرد در فرزندان مبتلايان

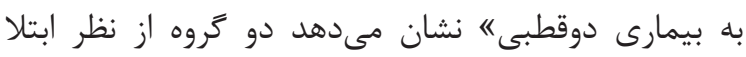

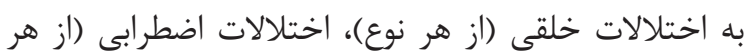

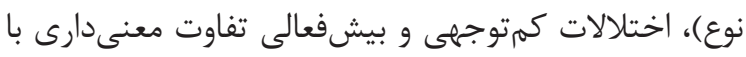

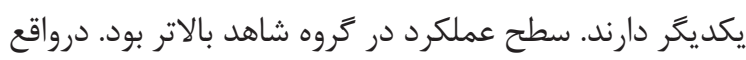
اختلالات روانيزشكى و افت عملكرد در فرزندان مبتلايان



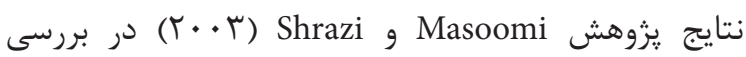
حالات روانى فرزندان والدين اسكيزوفرنيك نشان مى دهد كه

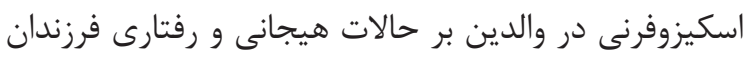

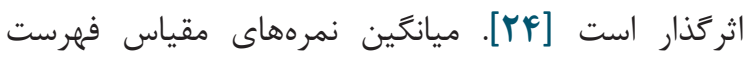

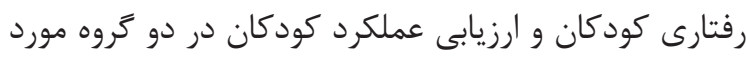

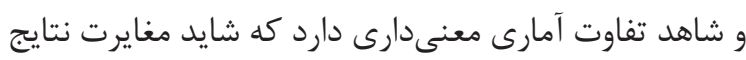
اين يزوهشها با يزوهش كنونى تفاوت در جمعيت مورد

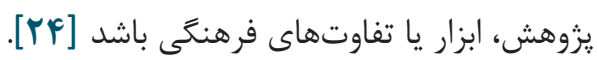

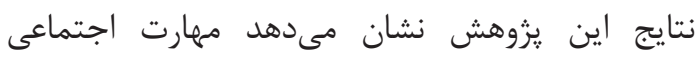


همكارى از كودكان با والدين مبتلا به اختلال روانى بالاتر



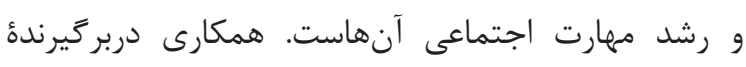
رفتارهايى مثل مشاركت با ديخران، بيروى از دستورالعملها و راهنمايىهاست. همجنين خردهمقياس مسئوليتيذيرى

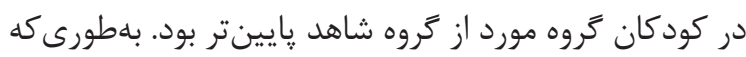

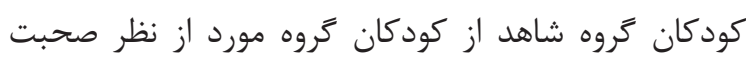
در مورد خود با كلمات مناسب، نشاندادن توجه و علاقئ كان كان خود به دوستان و همسالان، بيان احساسات هنكام خطا و

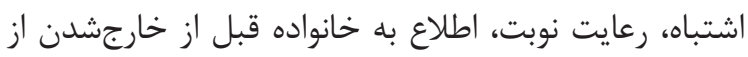

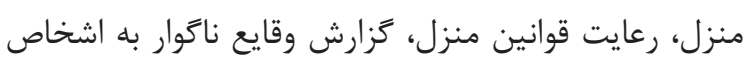
مناسب، پاسخدهى مناسب به تلفن و دوستداشتن توسط رئر

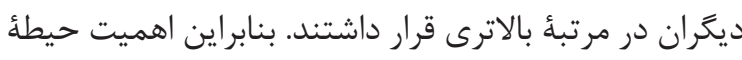

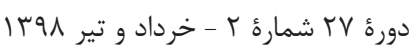

با استناد بر يافتههاى اين يزوهش، تنها فرضيئ اين يزوهش

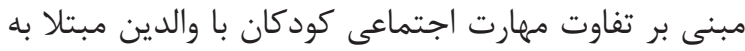

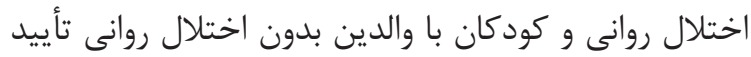

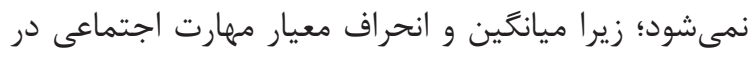

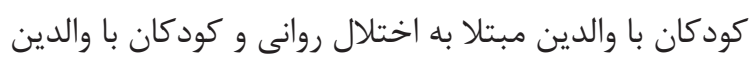
بدون اختلال روانى اختلاف معنىدارى نداشت. نتايج اين



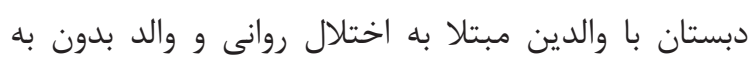
اختلال روانى در حد متوسط است.

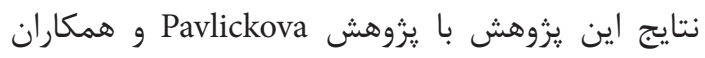

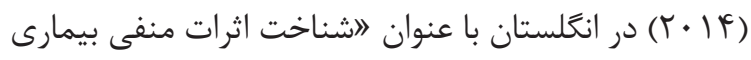

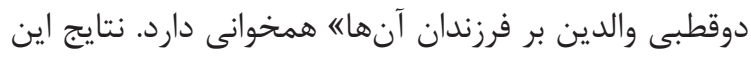
يزولهش نشان مى دهد كودكان با والدين دوقطبى در مقايسٔ

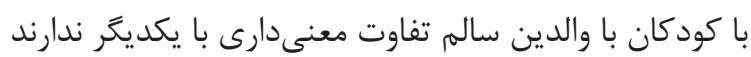

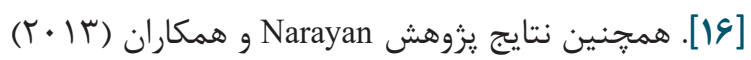
با عنوان ااختلال در آزمايش و تست واقعيت بهعنوان يك شاخص در كودكان با والدين مبتلا به اختلال دوقطبى" دماني

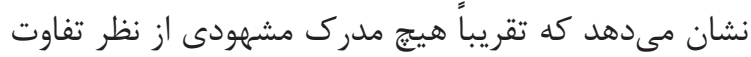

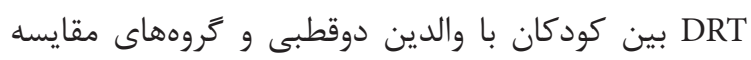

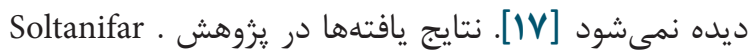

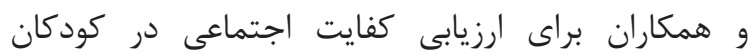

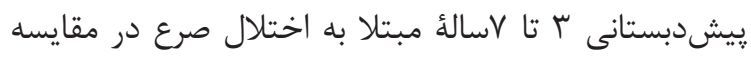

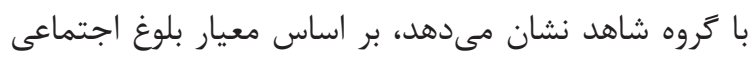

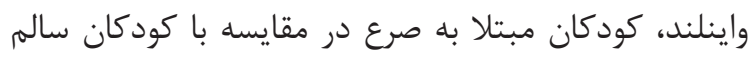

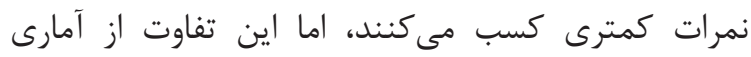

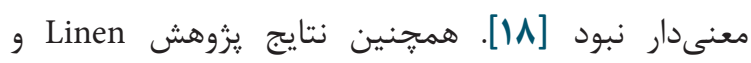

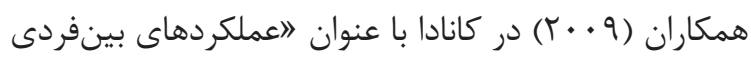
در نوجوانان با والدين مبتلا به بيمارى دوقطبى" نشان


وجود ندارد [19].

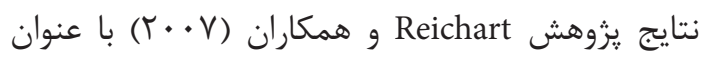

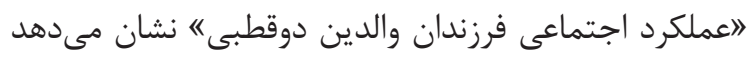

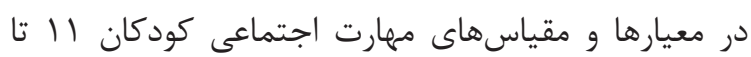

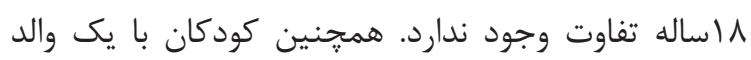

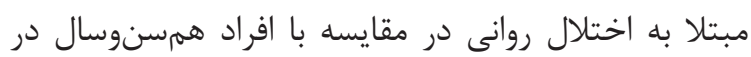

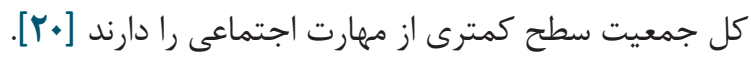

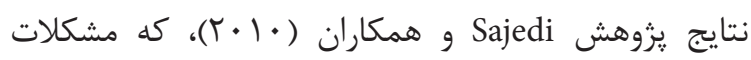
رفتارى كودكان را بررسى كردند، شيوع بالايى از مشكلات 
در تبيين يافتهاى اين يزوهش خويشتندارى به معنى كنترل رفتار، احساسات و غرايز است. خويشتندارى شامل رفتارهايى برائ مثل: مصالحه در مجادله يا نشاندادن رفتار معقول هنگام مسخرهشدن از سوى ديكران است كه در موقعيتهاى دشوار

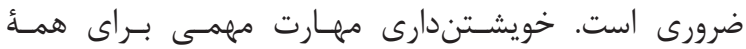

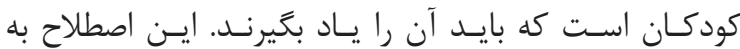
داشتن قدرت يا كنترل بر اعمال شخصى اشاره دارد. همجنين بــهـ ايـن معنسى اسـت كه افراد درست را از غلط تشخيص

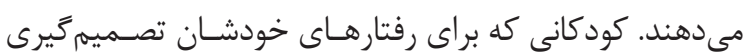
نمى كنند، به كودكان ديخر، والدين، معلمان يا بزر گَسالان تكيه

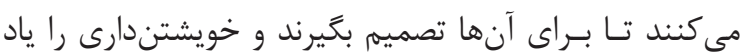
نمى تميرند [rr]

$$
\text { نتيجه تيرى }
$$

با توجه به اينكه ميزان نمرهٔ مهارت اجتماعى در كودكان با والدين مبتلا به اختلال روانى و بدون والدين مبتلا به اختلال روانى در اين يزوهش در حد متوسط بود. بازنخرى شيوههاى

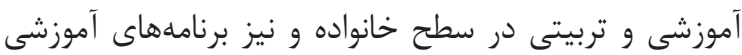
و يرورشى براى ارتقاو وتكامل مهارتهاى اجتماعى لازم است.

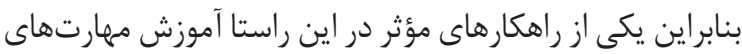
اجتماعى بلعنوان مداخلهاى يرستارى است.

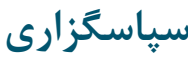

اين يزوهش نتيجهُ پاياننامة كارشناسى ارشد روانيرستارى

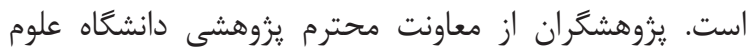
يزشكى همدان، كاركنان محترم بخشهاى روانيزشكى زنان زنان،

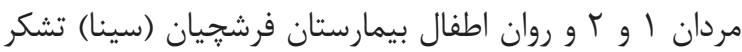

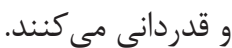

$$
\text { تعارض در منافع }
$$

بين نويسند كان هيجَّونه تعارضى در منافع وجود ندارد.

\section{References}

1. Stewart TC, West R, Coplan RJ. Multi-agent models of social dynamics in children. Cognitive Systems Research. 2007; 8(1):1-14.

2. Fyrs j, Trawl T. Clinical Psychology:Concepts, Methods and Professional [M Fyrvzbkht, Persian trans.]. Tehran: Roshd; 1393.

3. Shahim S. A study of the social skills in educable mentallyretarded children using The Social
مسئوليت پذيرى با اهداف يِيشخيرانه و ارتقاى سطح سلامت بهحدى است كه فقدان اين امر باعث مىشود فرد در برابر فشارها و استرسها به رفتارهاى غيرمؤثر و ״رخاشگرانه روى آورد. مسئوليتيذيرى شامل اعمالى است كه فرد در قبال عضويت در يك جامعه بايد براى آن جامعه انجام دهد. بهطوركلى مسئوليتيذيرى يعنى قابليت يذيرش و و باععهدهرفتن كارى كه از كسى خواسته شده است. در ارتباط با خردهمقياس قاطعيت كودكان گرووه مورد از گروه شاهد در سطح يايينترى بودند. بهطورى كه كودكان

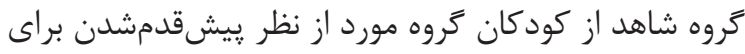
صحبت با ديخران، شركت در فعاليتهاى گروهى مثل ورزش،

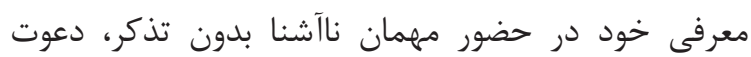
دوستان به خانه، دوستشدن با ديكران، قدردانى از دوستان، ييوستن به فعاليتهاى جمعى خانواده، اعتمادبهنفس بالا در

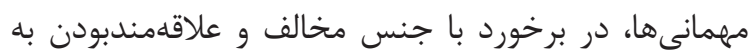
موارد متنوع مرتبـَ بالاترى داشتند. قاطعيت به اين مفهوم كه فرد احساسات مثبت و منفى مركى خود را بدون تجاوز به حقوق ديخران بيان كند. اين ويزگى

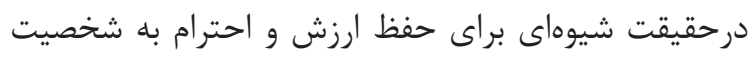
خود و ديخران است. افراد قاطع براى خود و ديگران احترام قائلاند، منفعل نيستند و اجازه سوءاستفاده نمى دهند. إن إن سوى ديخر آنها به خواستهها و نيازهاى ديخران احترام

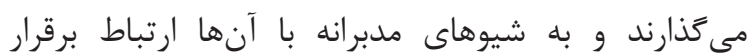
مى كنند [1.] در ارتباط با خردهمقياس خويشتندارى كودكان گروه شاهد از ₹روه مورد بهتر بودند. بلطورى كه كودكان گروه

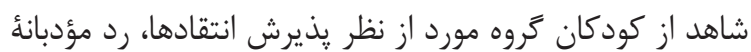
درخواست نامعقول ديخران، ياسخ مناسب به آزار و اذيت و رفتارهاى قلدرانهُ ديگران، دورى از دردسر، كنترل خشم هنگام بحث، اختلاف نظر و توافقنكردن با ديخران، صحبت با تن صداى مناسب و تغيير نظرات براى ايجاد توافق در سطح بالاترى بودند.

Skills Rating System. Journal of Psychology and Education. 1999; 4:18-37.

4. Fallahi Khesht MasjediM, Pasandideh MM. Psychometric properties of satisfaction with life scale in psychiatric patients. Iranian Journal of Psychiatry \& Clinical Psychology. 2016; 22(2):147-158.

5. Shamsaei F, Zolfagharjo R, Cheraghi F, Zamani G. Effects of Social Skills Training on Social Interactions of Children with Epilepsy. Iran J 
Psychiatry Behav Sci. 2017; 11(4):e9300.

6. Häyrynen E, Määttä K, Äärelä T, Uusiautti $\mathrm{S}$. There are not enough hours in a day to do everything": Parents' descriptions of everyday life with a child with severe physical disability. International Journal of Research Studies in Education. 2018; 8:1.

7. Liu J, Liu S, Yan J, Lee Mayes L. The impact of life skills training on behavior problems in left-behind children in rural China: A pilot study. School Psychology International. 2015; 37(1):7384.

8. Ashtari N, Pourebrahim T, Khodabakhshi Koolaee A, Khosh Konesh A, Khatiban M. The efficacy of group awareness training of premenstrual syndrome on psychological resilience and quality of life in female high school students. Scientific Journal of Hamadan Nursing \& Midwifery Faculty. 2015; 23(1):63-73.

9. Babakhanian $M$, Sayar S, Babakhanian M, Mohammadi G. Iranian children with ADHD and mental health of their mothers: The role of stress. Iran J Psychiatry Behav Sci. 2016; 10(1):e2026:1-4.

10. 10. Shamsaei F, Cheraghi F, Dehghani M, Jahangard L. Comparing Mental Health of School-Age Children of Parents With/Without Bipolar Disorders: A Case Control Study. Avicenna J Neuro Psycho Physiology. 2015; 2(2):44-48.

11. Eskandari Shahraki Z, Efffatpanah M, Gray S, RadfarM, Rezaei M, Hekmat H, et al. A Comparative Study of Psychiatric Disorders among Mothers of Children with Chronic Diseases and Mothers of Healthy Children. Journal of Applied Pharmaceutical Science. 2017; 7(12):116-120.

12. Amin A, Mojtaba A, Jamali S, Sarban MT. The effect of parental addiction on children>s behavior. Tolu Health. 2009; 8(3-4):31-40.

13. Hosseinkhanzadeh AA. Specific methods of assessment and teaching social skills in children with attention deficit/hyperactivity disorder.Journal of Exceptional Education.2013; 8(121):23-41.

14. Elliott SN, Malecki CK, Demaray MK. New directions in social skills assessment and intervention for elementary and middle school students. Exceptionality. 2001; 9(1-2):19-32.

15. Gresham FM. Teaching Social Skills to High-Risk Children and Youth: Preventive and Remedial
Strategies. 2002.

16. Pavlickova H, Turnbull O, Bentall RP. Cognitive vulnerability to bipolar disorder in offspring of parents with bipolar disorder. British Journal of Clinical Psychology. 2014; 53(4):386-401. doi: 10.1111/bjc. 12051

17. Narayan AJ, Allen TA, Cullen KR, Klimes Dougan B. Disturbances in reality testing as markers of risk in offspring of parents with bipolar disorder: a systematic review from a developmental psychopathology perspective. Bipolar Disorder. 2013; 15:723-740.

18. Soltanifar M, Moharreri F, Ashrafzadeh F, Yavari F. Social competence of preschool Children with Epilepsy Compared to Control Group. Journal of Mashhad University of Medical Sciences. 2013; 56(1):7-14.

19. Ellenbogen MA1, Santo JB, Linnen AM, Walker $\mathrm{CD}$, Hodgins S. High cortisol levels in the offspring of parents with bipolar disorder during two weeks of daily sampling. Bipolar Disorders. 2010; 12(1):77-86.

20. Reichart CG. Being a child of a bipolar parent. Psychopathology, social functioning and family functioning Erasmus Universiteit, Rotterdam. Altrecht Institute for Mental Health Care in Utrecht, Netherlands; 2005.

21. Sajedi Z, Zarabian M, Sadeghian E. Prevalence Behavior Disorders in 3 to 6 Years> Childrenin Hamadan City. Scientific Journal of Hamadan Nursing \& Midwifery Faculty. 2010; 18(1):1121.

22. Bella T, IbziakoP, Omigbodun O. Child psychiatric emergencies. Emergencies in Psychiatry in LowAnd Middle-Income Countries. 2013; 108.

23. Derahkshanpour F, Arabgol F, Panaghi L, Mazhabdar H. Psychiatric disorders and behavioral functions in offsprings of bipolar parents. Hormozagan Mediacl Journal. 2010; 13(4):246-252.

24. Masoomi A, Shrazi E. Psychiatric Status in Offspring of Schizophrenic Parents:A Comparative Study. Iranian Journal of Psychiatry and Clinical Psychology. 2006; 11(4):388-95. 